\title{
A Study of Immune Response in Nile Tilapia (Oreochromis niloti- cus) Fed Levamisole Incorporated Diet
}

\section{"Gebawo Tibesso Bedasso}

Batu Fishery and other Aquatic Life Research Center, Batu, Ethiopia

*Corresponding author: Gebawo Tibesso Bedasso, Batu Fishery and other Aquatic Life Research Center P.O. Box 229, Batu, Ethiopia; Tel: +251912152764; E-mail: nadhi2521@yahoo.com

Citation: Bedasso GT (2017) A Study of Immune Response in Nile Tilapia (Oreochromis niloticus) Fed Levamisole Incorporated Diet. J Fish Aqua Dev 2017: JFAD-106. DOI:10.29011/JFAD-106/100006

Received Date: 14 March, 2017; Accepted Date: 20 April, 2017; Published Date: 27 April, 2017

\begin{abstract}
This study was undertaken to evaluate the influence of levamisole on the immune enhancement of Nile tilapia (Oreochromis niloticus) against potential bacterial pathogens, Fish with weight of $98 \pm 5 \mathrm{~g}$ were randomly distributed into seven groups each at a rate of 20 fish per 300-L aquarium and fed on a diet containing 0.0, 250, 500, 750, 1000, 1250 or $1500 \mathrm{mg}$ levamisole/kg diet for eight weeks. After the feeding trial, fish were challenged by pathogenic Aeromonas hydrophila, E.coli, Staphylococcus aureus and Salmonella, which was given by Intra Peritoneal (IP) injection and Levamisole fed fish groups showed significant activation of non-specific immunological measures together with a relative enhancement of resistance against challenged bacteria. Interestingly, the indices study indicated that the fed group showed significant $(\mathrm{p}<0.05)$ increment in all immune parameters like phagocytic activity, serum bactericidal activity and leukocrit. The challenge studies (RPS) also clearly indicated that fish supplemented diet containing 1500 $\mathrm{mg}$ levamisole/kg diet showed high protection $(85 \%)$ over the control group. The lowest fish mortality and bacterial counts were obtained when fish fed diet containing 1.25-1.5g levamisole. These results indicate that levamisole supplementation is promising for disease prevention in tilapia culture.
\end{abstract}

Keywords: Levamisole, O. Niloticus, Immune System, Fish, Pathogenic Bacteria

\section{Introduction}

Aquaculture represents one of the fast growing food producing sectors and in the aim to increase productivity per unit space, fishes are usually cultured in narrow space such as pond or net cages under high densities, thus overcrowding tends to adversely affect the health of cultured fish making them a feasible target to infectious disease. As a consequence, several studies have looked into modulation of fish immune system in order to prevent the outbreak as reviewed recently by [1]. Disease outbreaks are increasingly being recognized as a potential constraint on aquaculture production and trade and cause massive financial loss either through mortality or reduced meat quality, resulting in reduced profit margins [2].

One of the major issues in intensive finfish aquaculture is loss associated with disease. A number of approaches have been applied in an attempt to address this problem including sanitary prophylaxis, disinfection, chemotherapy with a particular emphasis on the use of antibiotics, and in recent time's vaccination against specific diseases [3]. However there are practical difficulties and undesirable consequences associated with some, if not all of these approaches. For instance, prophylaxis, based on sanitary isolation is difficult to achieve due to the presence of other fish species, invertebrates or the water itself [3]. Antibiotic therapy is undesirable, as there is the potential for enhanced microbial resistance and the accumulation of residues in the tissues of the fish [4]. Vaccination, although highly effective in some instances, is time consuming, labor intensive and costly and protection is often pathogen specific [5]. An alternative approach has been the application of various compounds to boost or stimulate the innate immune system of cultured fish [6].

The use of chemicals to control bacterial and other parasitic infections in fish population resulted in bioaccumulation, human carryover and pollution. Similarly, the widespread use of antibiotics leads to development of antibiotic resistant bacteria, immunosuppressant and destabilization of helpful bacterial population. 
The application of antibiotics and other chemicals to pond culture is also quite expensive and undesirable, as it risks contamination of the environment and the final product as well as impaired growth. The use of antimicrobial drugs in Norway, a major fish producer, has dropped from approximately 50 metric tons per year in 1987 to $746.5 \mathrm{~kg}$ in 1997, measured as active components, and this is mainly due to mass vaccination and selection programs for important diseases [7].

Considering the recent successes of these alternative approaches, the Food and Agriculture Organization of the United Nations (FAO) defined the development of affordable yet efficient vaccines, the use of immunostimulants and non-specific immune enhancers, and the use of probiotics and bio-augmentation for the improvement of aquatic environmental quality as major areas for further research in disease control in Aquaculture [8]. One of the main emphases in Ethiopia is to develop aquaculture to its full potential making a big contribution to national food availability, food security, economic growth, and trade and improved living standards. However, along with the growing interest in the development of fish industries in the different sites of the area, there will be an increasing awareness of importance of fish disease as one of the major detrimental factors in culturing fish in the coming future.

\section{Objectives of the study were}

- To assess the concentration response and time course effects of levamisole treatment through oral route on selected components of the immune system of Nile tilapia (Oreochromis niloticus) and to evaluate the responses of levamisole treated Nile tilapia (Oreochromis niloticus) to the experimental bacterial challenge.

\section{Materials and Methods}

Fish and Husbandry Conditions: Fishes samples were collected using different centimeter mesh sizes of gillnets from selected water bodies. Gillnets will be set at certain study sites of the lake during day time and throughout the night. Immediately after capture, Total Length (TL) and Total Weight (TW) of each specimen will be measured to the nearest $0.1 \mathrm{~cm}$ and $0.1 \mathrm{~g}$, respectively. The fish was immediately disinfected with $3 \%$ sodium chloride for $5 \mathrm{~min}$ and they were kept for 2 weeks under observation for acclimatization in water tank. Fish was randomly distributed into each of 7 PVC tanks (300 liter capacity) filled with 150 liters of water. Each tank was supplied with aerated de-chlorinated fresh water every four days; water temperature was maintained at $25 \pm$ $1{ }^{\circ} \mathrm{C}$ with dissolved oxygen of $8.5 \mathrm{ppm}$.

Diet Preparation: A fish feed was prepared by first mixing dry ingredients fish meal together for 15 minute to ensure homogeneity and then adding in hot water. This mixture was steamed for $15 \mathrm{~min}$, allowed to cool and levamisole at 0.0, 250, 500, 750, 100, 1250 and $1500 \mathrm{mg} / \mathrm{kg}$ of diet was added to steamed and cooled feed mixture and then palletized. All pellets was separately air dried and stored in tightly sealed plastic bags at $8-10^{\circ} \mathrm{C}$ until they used in the feeding experiments. Levamisole Treatment: Fish was randomly distributed into each of 7 PVC tanks (300 liter capacity) filled with 150 liters aged tap water with continuous aeration. Fish in each tank were fed with $0.0,250,500,750,100,1250$ and $1500 \mathrm{mg}$ levamisole/kg diet, on the first day and every 3rdday for 16 days ( 7 doses, two divided doses per day) and fed with the control diet for the remaining days. Half of the water in each of the tanks was exchanged with fresh aged tap water every four days.

Blood Sampling: Collection of blood samples was taken place from five fish from each tank at 14 and 21 days after the last application of levamisole for immunological assay. Blood samples were taken from the fish by bleeding from caudal vein by using 21 $\mathrm{G}$ needles. Fish was anaesthetized in neutralized benzocaine (200 mg L-1) prior to blood sampling [9]. Haematocrit and leucocyte counts: At the end of the feeding trial, fish were fasted for 24 hours immediately prior to blood sampling and five fish per aquaria were randomly chosen and anesthetized with benzocaine (200 mg L-1). The blood was extracted from the caudal vein in Eppendorf tubes with sodium heparin ate $(500 \mathrm{U} / \mathrm{L})$, used as anticoagulant, for the counting of White Blood Cell (WBC) at 14 and 21 days after the last application of levamisole. For detection of the haematocrit levels, blood samples was taken into heparin zed capillary tubes and centrifuged in the haematocrit centrifuge at $2000 \mathrm{rpm}$ for $20 \mathrm{~min}$. Heamatocrit (PCV) value of each sample was measured using the haematocrit gauge. Total leucocyte count was determined using Shaw's solutions as dilution fluids following the method of [10]. A Blood smear of the fish was prepared, fixed in $100 \%$ methanol and stained with Wright-Giemsa stain. Different types of leucocytes were identified as described by [11].

Phagocytosis Assays: Phagocytic cells were detected using identified bacterial pathogen of fish as described by [12]. A sample $(0.1 \mathrm{~mL})$ of blood was placed in a micro titer plate well, $0.1 \mathrm{~mL}$ of Aeromonas hydrophila, E.coli, Staphylococcus aureus and Salmonella cells suspended in phosphate buffered saline was added and then mixed well. The bacteria-blood solution was incubated for 20 minutes at room temperature. $5 \mu \mathrm{L}$ of this solution was taken on to a clean glass slide and a smear was prepared. The smear was air dried, then fixed with ethanol $(95 \%)$ for 5 min and air dried. Then the smear was stained with Giemsa stain for $10 \mathrm{~min}$. The two smears were made from each fish. The total of 100 neutrophils and monocytes from each smear was observed under the light microscope and the number of phagocytizing cells and the number of bacteria engulfed by the phagocyte were counted. Phagocytic rate was calculated as follows: Phagocytic activity equals the number of phagocytizing cells divided by the total number of phagocytes counted.

$\mathrm{PR}=($ Number of phagocytes with engulfed bacteria/Number of phagocytes) X 100 
Relative percentage of survival: Bacterial pathogen was taken from Ethiopia Institute of Health and Nutrition Research and was inoculated in a tryptone soy broth and was incubated at $30^{\circ} \mathrm{C}$. After centrifugation at $800 \mathrm{~g}$ for $15 \mathrm{~min}$, the packed cells were washed and prepared in PBS. At the end of the study, fish in each aquarium were divided into two groups. The first group was challenged with $0.1 \mathrm{ml}$ dose from virulent bacterial pathogen. The second group was IP injected by $0.1 \mathrm{ml}$ of saline solution as a control. All groups were kept under observation for 10 days to record any abnormal clinical signs and the daily fish [13]. Relative Percentage Survival (RPS) was calculated as follows: Mortality (\%) of untreated minus Mortality (\%) of treated divided for Mortality (\%) of untreated controls multiply by 100 .

Bacteriocidal Activity: Bacteriocidal activity in fish samples mortality rate. The cause of death was ascertained by re-isolating the bacteria from the kidney and liver of dead was analyzed according to the Miles-Misra technique [14]. Aeromonas hydrophila, E.coli, Staphylococcus aureus and Salmonella used in this assay was stocked at $-80^{\circ} \mathrm{C}$ in glycerol solution. This strain was inoculated with tryptone soy broth (TSB). Bacteria culture was grown for $24 \mathrm{~h}$ at $30 \mathrm{oC}$ on TSB medium, and the culture broth was centrifuged, washed with saline solution and suspended in Gelatin Veronal Buffer (GVB). Viable counting was conducted by inoculating with serial dilution in GVB on tryptone soy agar (TSA). The serum sample was mixed with GVB $(1: 1 \mathrm{v} / \mathrm{v})$ and stored at $4 \mathrm{oC}$. Serum samples were mixed with an equal volume of bacterial suspension and incubated at $30 \mathrm{oC}$. The number of viable bacteria was then calculated by counting the resultant colonies from the incubated mixture on TSA (Tryptic Soy Agar) plates after incubation for $24 \mathrm{~h}$ in duplicate

Data Management and Analysis: Statistically data was analyzed using descriptive statistics and mean comparison procedure of the Statistical Package for Social Science Software (SPSS 20.0).

\section{Results and Discussions}

Fish fed on diets containing 750-1500mg levamisole $/ \mathrm{kg}$ diet exhibited similar RBC and WBCs counts and their ranges were $2.22-2.64 \times 10^{6} / \mu \mathrm{L}$ and $3.39-4.34 \times 10^{5} / \mu \mathrm{L}$, respectively. The low counts of RBCs and WBCs were obtained at the control diet 1.66 x $10^{6} / \mu \mathrm{L}$ and $2.94 \times 10^{5} / \mu \mathrm{L}$, respectively (Table 1 ). No significant changes in lymphocytes were observed at $750-1500 \mathrm{mg} / \mathrm{kg}$ diet, whereas the lowest one was observed at the control diet (81.4\%). Contrarily, the control diet produced the highest monocytes and granulocytes, which decreased with the increase of Levamisole levels in fish diet $(P<0.05$; Table 1$)$. The bacterial count after incubation with fish sera decreased with increase of levamisole level in fish diets. The lowest bacterial count was obtained in fish fed $750-1500 \mathrm{mg}$ levamisole/kg of diet, whereas the highest one was obtained when fish fed control diet (Table 2).

Fishes fed with higher concentration (750-1500mg levamisole/kg of diet) showed significant survival rate when challenged with Aeromonas hydrophila, E.coli, Staphylococcus aureus and Salmonella. High mortality rate was observed in control group. The experimental groups that received low doses of levamisole showed mortality at a lower rate when compared to that of control group. The total fish mortality 10 days after IP with pathogenic bacteria decreased significantly $(\mathrm{P}<0.05)$ with the increase of levamisole supplementation (Fig. 1). No significant leukocyte concentration (x103cells $/ \mathrm{mm} 3$ ) was observed in throughout the study period. The group fed $1500 \mathrm{mg} / \mathrm{kg}$ levamisole supplemented diet showed elevated leukocrit value, but not statistically significant one ( $p>0.05)$. Phagocytosis Rate (PR) on bacterial cells was not much influenced by levamisole supplementation but in high dosages PR was significant $(p<0.05)$ than control and other group. The groups fed with lower concentration of levamisole did not showed significant bactericidal activity $(\mathrm{p}>0.05)$ but higher concentration $(1500 \mathrm{mg} / \mathrm{Kg})$ showed significant bactericidal activity $(\mathrm{p}<0.05)$.

\begin{tabular}{|c|c|c|c|c|c|c|c|}
\hline \multirow{2}{*}{ Items } & \multicolumn{7}{|c|}{ Levamisole levels (mg/kg diet) } \\
\cline { 2 - 8 } & $\mathbf{0 . 0}$ & $\mathbf{2 5 0}$ & $\mathbf{5 0 0}$ & $\mathbf{7 5 0}$ & $\mathbf{1 0 0}$ & $\mathbf{1 2 5 0}$ & $\mathbf{1 5 0 0}$ \\
\hline RBC $\left(\mathrm{x} 10^{6} / \mu \mathrm{L}\right)$ & $1.66 \pm 0.087 \mathrm{~b}$ & $1.92 \pm 0.079 \mathrm{~b}$ & $2.07 \pm 0.127 \mathrm{ab}$ & $2.22 \pm 0.153 \mathrm{a}$ & $2.48 \pm 0.158 \mathrm{a}$ & $2.54 \pm 0.127 \mathrm{a}$ & $2.64 \pm 0.138 \mathrm{a}$ \\
\hline WBC $(\mathrm{x} 105 / \mu \mathrm{L})$ & $2.94 \pm 0.124 \mathrm{~b}$ & $3.21 \pm 0.133 \mathrm{~b}$ & $3.29 \pm 0.176 \mathrm{ab}$ & $3.39 \pm 0.098 \mathrm{a}$ & $3.97 \pm 0.127 \mathrm{a}$ & $4.02 \pm 0.133 \mathrm{a}$ & $4.34 \pm 0.136 \mathrm{a}$ \\
\hline Lymphocytes $(\%)$ & $81.4 \pm 0.19 \mathrm{c}$ & $86.1 \pm 1.59 \mathrm{bc}$ & $92.2 \pm 2.52 \mathrm{bc}$ & $94.1 \pm 2.71 \mathrm{ab}$ & $94.1 \pm 2.71 \mathrm{ab}$ & $96.3 \pm 2.62 \mathrm{ab}$ & $97.8 \pm 0.233 \mathrm{ab}$ \\
\hline Monocytes $(\%)$ & $11.2 \pm 0.18 \mathrm{a}$ & $9.1 \pm 0.16 \mathrm{a}$ & $5.5 \pm 0.19 \mathrm{~b}$ & $4.6 \pm 0.15 \mathrm{~b}$ & $4.6 \pm 0.15 \mathrm{~b}$ & $2.8 \pm 0.06 \mathrm{c}$ & $1.9 \pm 0.08 \mathrm{c}$ \\
\hline Granulocytes $(\%)$ & $7.4 \pm 0.13 \mathrm{a}$ & $4.8 \pm 0.03 \mathrm{~b}$ & $2.3 \pm 0.06 \mathrm{c}$ & $1.3 \pm 0.06 \mathrm{c}$ & $1.3 \pm .0 .06 \mathrm{c}$ & $0.9 \pm 0.06 \mathrm{~d}$ & $0.3 \pm 0.05 \mathrm{~d}$ \\
\hline
\end{tabular}

Table1: Red Blood Cell Count (RBC), White Blood Cell Count (WBC), lymphocytes, monocytes and granulocytes of Nile tilapia fed practical diets containing different levels of levamisole for 8 weeks.

Note: The same letter in the same row is not significantly different at CI of $95 \%$. 


\begin{tabular}{|c|c|c|c|c|c|c|c|}
\hline \multirow{2}{*}{ Item } & \multicolumn{7}{|c|}{ Levamisole levels (mg/kg diet) } \\
\cline { 2 - 7 } & $\mathbf{0 . 0}$ & $\mathbf{2 5 0}$ & $\mathbf{5 0 0}$ & $\mathbf{7 5 0}$ & $\mathbf{1 0 0}$ & $\mathbf{1 2 5 0}$ & $\mathbf{1 5 0 0}$ \\
\hline $\begin{array}{c}\text { Bacterial count } \\
(\mathrm{x} 104 \text { cell) }\end{array}$ & $82.7 \pm 3.28 \mathrm{a}$ & $68.0 \pm 1.73 \mathrm{~b}$ & $61.2 \pm 1.73 \mathrm{c}$ & $46.7 \pm 2.96 \mathrm{~d}$ & $42.3 \pm 2.03 \mathrm{~d}$ & $43.3 \pm 2.03 \mathrm{~d}$ & $33.2 \pm 2.03 \mathrm{~d}$ \\
\hline
\end{tabular}

Table 2: The total counts of bacteria $24 \mathrm{hr}$-after incubation with serum of Nile tilapia fed different levels of levamisole for 8 weeks.

Note: The same letter in the same row is not significantly different at CI of $95 \%$.

\begin{tabular}{|c|c|c|c|c|c|c|c|}
\hline \multirow{2}{*}{ Items } & \multicolumn{7}{|c|}{ Levamisole levels (mg/kg diet) } \\
\cline { 2 - 8 } & $\mathbf{0 . 0}$ & $\mathbf{2 5 0}$ & $\mathbf{5 0 0}$ & $\mathbf{7 5 0}$ & $\mathbf{1 0 0 0}$ & $\mathbf{1 2 5 0}$ & $\mathbf{1 5 0 0}$ \\
\hline Phagocytic Rate & $36.66 \pm 2.7 \mathrm{~b}$ & $37.7 \pm 2.9 \mathrm{~b}$ & $38.34 \pm 2.7 \mathrm{~b}$ & $37.5 \pm 1.53 \mathrm{~b}$ & $39.48 \pm 1.58 \mathrm{~b}$ & $42.54 \pm 1.27 \mathrm{~b}$ & $51.4 \pm 1.38 \mathrm{c}$ \\
\hline Bactericidal Activity & $0.02 \mathrm{a}$ & $0.06 \mathrm{a}$ & $0.07 \mathrm{a}$ & $0.07 \mathrm{a}$ & $0.06 \mathrm{a}$ & $0.07 \mathrm{a}$ & $0.11 \mathrm{~b}$ \\
\hline $\begin{array}{c}\text { Leukocrit (x103cells/ } \\
\mathrm{mm} 3\end{array}$ & $22.4 \pm 1.9 \mathrm{c}$ & $24.2 \pm 2.1 \mathrm{c}$ & $22.23 \pm 1.5 \mathrm{c}$ & $23.12 \pm 1.3 \mathrm{c}$ & $21.1 \pm 1.7 \mathrm{c}$ & $22.26 \pm 1.6 \mathrm{c}$ & $26.7 \pm 1.3 \mathrm{c}$ \\
\hline PRP (\%) & $0 \mathrm{a}$ & $20 \mathrm{a}$ & $40 \mathrm{a}$ & $75 \mathrm{c}$ & $80 \mathrm{c}$ & $80 \mathrm{c}$ & $85 \mathrm{c}$ \\
\hline
\end{tabular}

Table 3: The immune parameters of Nile tilapia fed with different levels of levamisole in water tank for 8 weeks

Note: The same letter in the same row is not significantly different at CI of 95\%.

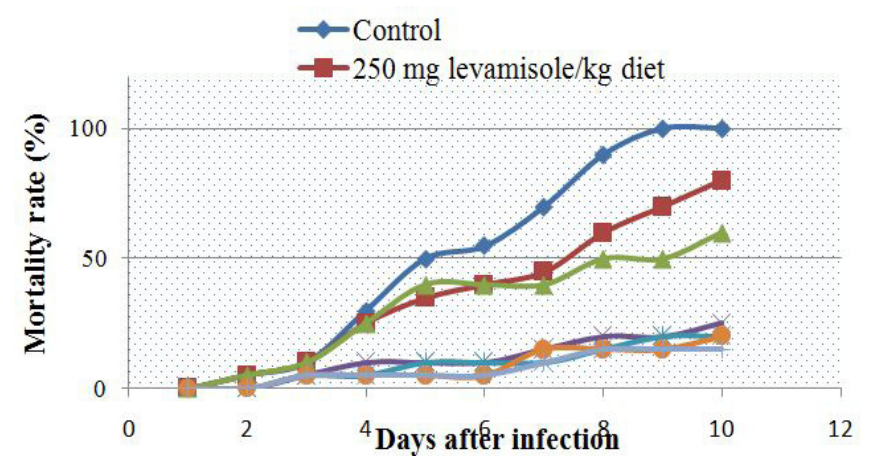

Figure1: Mortality rate of Nile tilapia fed with different levels of levamisole in water tank for 8 weeks and challenged by bacteria for 10 days

Application of immunostimulators in the aquaculture industry can be considered a remarkable advantage because of their safety and the fact that they are considered environmentally friendly $[15,16]$. Levamisol has been found to stimulate the immune responses significantly in both in vitro and in vivo in mammals. In the present study, oral administration of Levamisole increased serum lysozyme activity in all groups which receive Levamisole than normal control groups. It has been observed that immune stimulants, vaccines and probiotics can enhance the plasma lysozyme activity $[17,18]$. Lysozymal activity is an important defense mechanism in fish, which causes lysis of bacteria and activation of the complement system and phagocytes by acting as an opsonin.

In the present study, fish fed on diets containing $750-1500 \mathrm{mg}$ levamisole $/ \mathrm{kg}$ diet exhibited higher RBCs and WBCs counts, as compared with fish fed the control diet. These results proved the improvement of fish health when fed levamisole-supplemented diets. No significant changes in lymphocytes were observed at 750-
$1500 \mathrm{mg} / \mathrm{kg}$ diet, whereas the lowest one was observed at the control diet (81.4\%). Contrarily, the control diet produced the highest monocytes and granulocytes, which decreased with the increase of Levamisole levels in fish diet.

In the present study, the results of bacteria challenge and bacteriocidal activity suggest the increase in phagocytosis in blood at higher levamisole level, which have an important role for prevention of infectious disease. Phagocytosis by these cells is a process of internalization, killing and digestion of invading microorganisms. In phagocytosis, phagocytes produce oxygen free radicals during the respiratory burst, which is toxic to bacteria. Several authors reported that phagocytosis is stimulated by oral administration of probiotics $[16,19,20]$.

It is very important to estimate the useful impacts on fish treated with immuno-stimulants. In this study, the obtained results showed that tilapia fed 750-1500mg levamisole $/ \mathrm{kg}$ diet increased the fish resistance against bacterial challenge. In this regard, estimated the fluctuation in the number of bacterial cells in Spirulinatreated fish organs after an artificial challenge with $A$. hydrophila [21]. They found that the bacteria numbers were lower in the liver and kidney of carp treated with Spirulina than the control group suggesting the increased resistance $A$. hydrophila infection. The present study concluded that levamisole positively improved resistance to bacterial infection of Nile tilapia. In addition, this study found that the optimum rate of levamisole in the fish practical diet is $750-1500 \mathrm{mg}$ levamisole $/ \mathrm{kg}$ diet.

\section{References}

1. Sakai M (1999) Current research status of fish Immunostimulants. Aquaculture 172: 63-92. 
2. Smith VJ, Brown JH, Hauton C (2003) Immunostimulation in crustaceans: does it really.

3. Chevassus B, Dorson M (1990) Genetics of resistance to disease in fishes. Aquaculture 85: 83-107.

4. Siwicki AK (1989) Immunostimulating influence of levamisole on nonspecific immunity in carp (Cyprinuscarpio). Developmental and Comparative Immunology 13: 87-91.

5. Robertsen B, Engstad RE, Jorgensen JB (1994) Glucans as immunostimulants. In Modulators of Fish Immune Responses, vol. 1 (Stolen J, Fletcher TC, Eds) 83-99.

6. Castro R, Couso N, Obach A, Lamas J (1999) Effect of different betaglucans on the respiratory burst of turbot (Psetta maxima) and gilthead seabream (Sparusaurata) phagocytes. Fish \& Shellfish Immunology 9: $529-541$.

7. Verschuere L, Rombaut G, Sorgeloos P, Verstraete W (2000) Probiotic bacteria as biological control agents in Aquaculture. Microbiology and Molecular Biology 159-160 Reviews 64: 655-671.

8. Subasinghe R (1997) Fish health and quarantine. In: Review of the State of the World Aquaculture. FAO Fisheries Circular No. 886.Food and Agriculture Organization of the United Nations, Rome, Italy 45: 9.

9. Treves-Brown KM (2000) Applied Fish Pharmacology. Kluwer Academic Publishers, Dordrecht, the Netherlands 309.

10. Hesser EF (1960) Methods for Routine Fish Haematology. Progressive Fish Culturist 22:164-171.

11. Hibiya T (1982) An Atlas of Fish Histology-Normal and Pathological Features. Kodansha, Tokyo, Japan. Protect against infection? Fish and Shellfish Immunology 15: 71-90.

12. Siwicki AK (1987) Immunomodulating activity of levamisole in carp spawners, CyprinuscarpioL. J Fish Biol 31: 245-246.
13. Misra CK, Das BK, Mukherjee SC, Meher PK (2006) Theimmunomodulatory effects of tufts in on the non-specific immune system of Indian Major Carp, Labeorohita. Fish Shellfish Imm 20: 728-738.

14. Okada YNJ, Klein, Pierro J (1999) Neutrophil dysfunction: The cellular mechanisms of impaired immunity during total parenteral nutrition in infancy. J. Pediatr. Surg 34: 242-245.

15. Dügenci SK, Arda N, Candan A (2003) some medicinal plants as immunostimulant for fish. Journal of Ethno pharmacology 88: 99-106.

16. Li P, Gatlin DM (2004) Dietary brewer's yeast and the prebiotic GroBiotickTM AE influence growth performance, immune responses and resistance of hybrid striped bass (Moronechrysopsx M. saxatilis) to Streptococcus iniae infection. Aquaculture 231: 445-456.

17. Swain PS, Dash PK, Sahoo P, Routray SK, Sahoo SD, et al. (2006) Non-specific immune parameters of brood Indian major carp Labeorohita and their seasonal variations. Fish and Shellfish Immunology 22: $38-43$.

18. Yuan C, Li D, Chen W, Sun F, Wu G, et al. (2007) Administration of an herbal immunoregulation mixture enhances some immune parameters in carp (Cyprinuscarpio). Fish Physiol. Biochem 10: 1007-1120.

19. Rengpipat S, Rukpratanporn S, Piyatiratitivorakul S, Menasveta P (2000) Immunity enhancement in black tiger shrimp (Penaeusmonodon) by a probiont bacterium (Bacillus S11). Aquaculture 191: 271-288.

20. Panigrahi A, Kiron V, Puangkaew J, Kobayashi T, Satoh S (2005) The viability of probiotic bacteria in rainbow trout Oncorhynchusmykiss. Aquaculture 243: 241-254.

21. Watanuki H, Ota K, Malin AC, Tassakka AR, Kato T, et al. (2006) Immunostimulant effects of dietary Spirulinaplatensis on carp, Cyprinuscarpio. Aquaculture 258: 157:163 